\title{
Continuous Innovation: A Literature Review and Future Perspective
}

\author{
Benny Lianto $^{\#}$, M.Dachyar", Tresna Priyana Soemardi ${ }^{\#}$ \\ ${ }^{\#}$ Departement. of Industrial Engineering, University of Indonesia, Jl. Margonda Raya, Depok, Jawa Barat 16424, Indonesia \\ E-mail: benny.lianto@ui.ac.id,mdachyar@ui.ac.id,tresnasoemardi@ui.ac.id
}

\begin{abstract}
Continuous Innovation (CI) has become one of the hot topics in innovation management field. However, studies focusing on the comprehensive and detailed explanation of CI concept are still limited. This paper aims to elaborate on CI concept using three fundamental questions: WHAT (what is the definition of CI and what are the determining factors?), WHY (why do companies need CI?), and HOW (how can companies develop CI?). The purpose of this paper is also to contribute in giving an understanding that is more exhaustive on CI definition, the importance of CI for companies, necessary elements in determining CI capability, and various strategies for CI development. From this literature study, a new and more comprehensive definition of CI was found, which categorized the reason why the companies need the CI and identified essential elements in determining CI capability. In addition, the mapping process produced a description of the proportion of CI development strategy as follows: technology-based (11\%), People based $(15 \%)$, organizational \& system based (32\%), strategic-based (11\%), knowledge-based (22\%) and collaborative \& connectivity based (9\%). It can be observed that current CI development strategies still focus on organizational, system based approach, and most of them $(\mathbf{8 1 \%})$ rely on the internal resources of the company. Future perspectives, in this digital and internet era, which provides connectivity and the shift of the concept of, own economy to sharing economy; companies will have big potentials to work on innovation collaboratively. CI concept development should consider open innovations instead of today's "do-it-yourself" mentality (closed innovation).
\end{abstract}

Keywords - continuous innovation; literature review; open innovation

\section{INTRODUCTION}

Continuous Innovation (CI) is currently one of the most discussed topics in innovation management sector. A quick look on Google Scholar search yields 2,850,000 hits for keywords "continuous innovation." [Google scholar, May 2017]. This shows that CI has become a center of attention to researchers and practitioners. Furthermore, CI has been set as one of the primary goals for multiple companies [1]. $\mathrm{CI}$ is the engine that drives highly successful companies such as Apple, Google, Honda, Hewlett-Packard, Microsoft, General Electric, P\&G, Sony, and Tata Group [2]. However, the studies discussing and describing the CI concept comprehensively are still insufficient [3]. Companies still have a limited understanding of the CI concept [4]. Accordingly, many of those companies, especially the largescale companies, lose the ability to retain and enhance their innovation capabilities.

The studies on the CI and its application in various sectors, scales, and types of industry, such as manufacture industry [5], [6], services industry [7], [8], social sector [9], high-tech industrial cluster [10], Small and Medium-sized enterprises or clusters [11], [13], mature and slow moving industry [14], and rapidly changing industry [15], indicated that there are different definitions and concept of "continuous innovation". The connotation of the word "continuous" in several studies are sometimes linked to the extent to which the innovation change is made, such as continuous improvement [16]. Gradual innovation [17], incremental innovation [18], which tend to see the CI as a small and gradual change. On the other hand, the CI is often linked with the concept of discontinuous innovation [19], and radical innovation [20] tend to direct the CI concept to produce a significant change in facing a dynamic and unstable situation [21]. Therefore, the CI concept has several things in common with the concept of organization resilience [22], and dynamic innovation [23].

The word "continuous" also can be interpreted as a sustainable effort in building the ability to innovate continuously [15]. Several researchers use different terms such as sustainable innovation [1], [13]. The contradiction between Continuous vs. discontinuous innovation, incremental vs. radical innovation, and continuous vs. sustainable innovation causes researchers and practitioners to have difficulty understanding the concept of CI well. In addition to the CI definition problem, the determinants of CI's capabilities are also compelling to be studied comprehensively. Some studies show that CI performance is 
profoundly affected by continuous innovation capabilities. Therefore, every company is concerned about the determinants of CI capability.

CI capability can be defined as a cluster of fundamental elements, and general characteristics of a company or organization used to facilitate and or support CI-related activities. The fundamental elements are different abilities of a company, serving as assets and unique resources for them to perform innovation activities [24]. Most studies on CI so far focus more on efforts to determine the factors that affect the capabilities CI [1], but most of the factors used are concerned more on real and monetary based CI elements and dimensions [25], [26], [28]. Some of the most frequently used CI capability factors or elements are the number of product innovation, the number of process innovation number of patents, R\&D activities productivity, and total cost of R\&D. The crucial element of CI capability in the last decade is shifting along with the emergence of a new environmental order in the world of business and industry. Wang studied a concept of innovation capability under uncertainty [29]. On the other hand, another study revealed that in a dynamic business environment, it is insufficient for a company to "do things better" [30]. To survive and to compete in a dynamic environment, companies must change their paradigm to "do things differently." The paradigm can only be applied if companies possess the high capability and sufficient knowledge capital. Studies and research focusing on determining elements in CI capabilities have been growing and keep adjusting to the demands of change. The comprehensive identification of CI determinants of capabilities is crucial for corporate managers to get a picture of the CI's capability factors relevant to today's business environment demands.

On the other hand, the question of why and at what point a company needs to develop CI capabilities and how CI's capability development strategy is, can be another matter that has not received adequate answers. Therefore, it is interesting to review it comprehensively to contribute to the development of CI concepts and theories in the future.

This paper aims to elaborate on CI concept using three basic questions: WHAT (what is the definition of CI and what are the determining factors?), WHY (why do companies need CI?), and HOW (how can companies develop CI?). The result of this paper not only lays a theoretical foundation for further research but also provides a clear ground of CI for business and industries to improve their continuous innovation capabilities and their adaptation to the dynamic business environment.

\section{MATERIAL AND METHOD}

Systematic literature review methods were employed to answer the three primary research questions: WHAT (what is the definition of CI and what are the determining factors?), WHY (why do companies need CI?), and HOW (how can companies develop CI?. The review process was initiated by identifying and selecting the article. The paper identification and selection process in this literature study used the keywords "continuous innovation" from 3 journal databases: EBSCO, Emerald, and Wiley Interscience. The selected papers were those published in international journals in 1989 up to 2017 and were in English (inclusion criterion). There were 1959 original papers obtained from this step. Two exclusion criterions were then applied to those papers: filtering out papers with no explicit continuous innovation words on their title and abstract (EC1) and filtering out papers with no contents of one of three questions used in this study (EC2). The remaining articles were 49 . The process as described below:

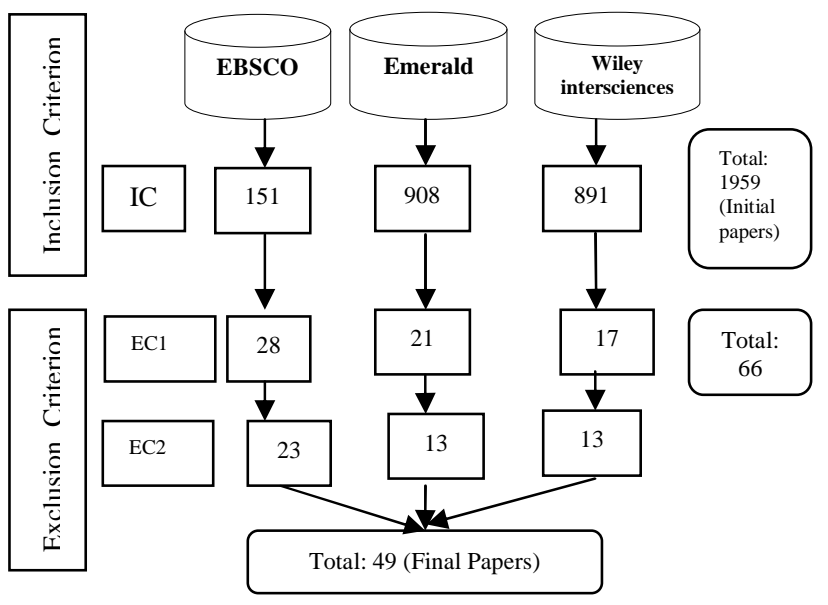

Fig. 1 Journal selection stages

The next step was to review the contents of selected articles by identifying and recording aspects related to the reasons why the company needs $\mathrm{CI}$, the definitions, and concepts of CI, the determinants of CI's capabilities and the company's efforts and strategy in developing CIs. Furthermore, the results of the review were analyzed and reviewed by conducting the process of categorization, mapping, and formulation.

\section{RESULT AND DISCUSSION}

\section{A. Categorization of CI Definition}

From the result of the literature review, we tried to categorize the various definitions of CI. The basis used in conducting the categorization process is the magnitude of innovation change (incremental or radical) is irrelevant to controversy [15]. The definition is more directive in that CI is a continuous process in generating incremental or radical innovation combinations.

Based on that idea, the definition of continuous innovation can be categorized into three as follows:

- An innovation process and activity performed continuously, regularly, routinely, in a structured way, and over an extended period; making a significant impact on a company. There are three primary characteristics of CI [1]: persistence, sustainable economic growth, and sustainable development of enterprises. Based on those characteristics, CI falls into a definition of continuous and sustainable process to achieve economic growth and business development as a concept of Enterprise Sustainable Innovation [31]. It was explained as a long- 
time process in which a company continually introduces and implements innovation projects and generating impact from those projects. CI is a continuous interaction process between operation, gradual improvement, learning process, and radical innovation stem from a compelling combination of operational and strategic aspects [17].

- The ability of a company to continuously learn and reinvent itself to create new products, processes, organizations and business models [6]. It is asserted that the conceptuality of CI consists of at least three main elements [16]: continuous improvement, learning, and innovation. Continuous and effective interaction of continuous improvement, learning, and innovation will guarantee a sustainable innovation [20]. An organizational concept of renewal capability [6] highlighted a situation when a company is continuously self-reinvents, the company will have the capability to develop, change, modify, and organize resources, knowledge, assets, and their routine activities to properly maintain business competitiveness. CI is achieved through the interaction of learning process, operation process, humans, and technology [7].

- The ability of a company to act fast and to adapt to current and future customers' need. CI is the capacity for "timely responsiveness and rapid product innovation, coupled with the surveillance of regulatory policies, technologies, and the capability to quickly accomplish changes while being and staying successful in the marketplace at management capability to effectively coordinate and redeploy internal and external competencies" [32]. CI is the capacity to combine excellence today with activities aimed at achieving excellence tomorrow and the day after tomorrow [21].

Based on the category of CI definition above, CI can be comprehensively defined as an innovation process and activity performed continuously, regularly, repeatedly, in an extended period, which results in beneficial impact for a company. In extension, it will create a learning culture, of which an organization has the purpose to continuously improve and self-renew to adapt to the ever-changing consumers' need in the time being and the future.

This definition is more directive in that $\mathrm{CI}$ is a continuous process in building and forming the capabilities of innovation to increase the potential of a company in generating innovation performance (a combination of incremental or radical innovation) continuously. This is the new definition of CI that will be the basis of understanding for future development strategies for CI.

\section{B. Categorization of Reason Why Companies Need CI}

Based on a literature study, we listed several reasons why companies need CI (see Table 1). Various reasons put forward, in principle, can be grouped into four main reasons, that is,

1) Turbulent Competitive Environment and Dynamic Environment. The dynamic business environment has one characteristic: Unexpected changes often occur. An organization thus must act fast to adapt to predictable or unpredictable changes. Furthermore, a company also must be able to anticipate change by understanding early warnings and taking necessary steps to overcome the challenges. In such condition, CI is needed. CI is the capacity for "timely responsiveness and rapid product innovation, coupled with the management capability to effectively coordinate and redeploy internal and external competencies" [32]. CI is the capacity to combine excellence today with activities aimed at achieving excellence tomorrow and the day after tomorrow [21].

2) Global Competition and Economy. Globalization places companies in competition with virtually all companies around the globe. This situation drives companies to perform in line with excellent standard, being more efficient, increase products quality, improve their service, and guarantee continuous product supply. It also means companies need to continuously improve and reinvent themselves to maintain the standard [6], [8], [33].

3) Customization and High Variety of Customers Demand. With customers demanding a high variety of products, shorter products life cycle, and increasing demand for fast and on-time service; companies are expected to shorten their product development and increase new products introduction. In other words, companies need to perform continuous innovation and development in their products and services are relevant to customers' needs [34], and

4) Rapid Development of ICT and Digital System. The fast development of information and communication technology (ICT) as well as the digital system in business create a significant impact for innovation process in a company. Costumes now possess more information, and in extension options, to choose a particular product due to the massive and vast spread of information and knowledge. This condition prompts companies to improve and adjust their products and service to keep in line with customers' demand [35].

In summary, it can be said that companies need CI to overcome challenges driven by hyper-competition, globalized world, rapid technology advancement, shortening of product life, and more dynamic business environment. A dynamic and unstable business environment has one unique characteristic, i.e., unexpected changes often happen. An organization them must act fast to adapt and anticipating changes, understand the signs, and must be able to take necessary steps to avoid or to adapt. On the other hand, globalization puts companies in an awkward position to compete with the rest of the world. This condition forces companies to continuously improve and self-renew so as their product, process, organization, and service fall into world-class standard [6], [33], [8]. Another challenge is the change in consumers' demand. They are various, unique, and extended as well as shorter in the form of life cycle product. More consumers also demand faster and more punctual service. All of them prompt companies to shorten their product development and increase product release. Companies must perform innovation continuously in their process, products, and services to be relevant to current 
consumers' needs [17], [34]. The pressure for companies to increase their capability in innovation is getting more intense with the fast development of information and communication technology and digitalization in business. The flow of information and knowledge drives consumers to be more aware and careful in choosing the best product and service. Regarding this challenge, companies must continue to improve and adapt to the change in consumers' demand [34]-[35].

TABLE I

SOME REASON WHY COMPANIES NEED CI

\begin{tabular}{|c|c|}
\hline Why the Company need of CI & Sources \\
\hline $\begin{array}{l}\text { To survive in demanding and turbulent competitive environment. Companies need to reduce product development intervals } \\
\text { and to increase the frequency of new product introduction continuously (Continuous product innovation) }\end{array}$ & [17] \\
\hline $\begin{array}{l}\text { The severe global competition requires ever shortening lead times: more and more quickly, with less cost but high quality, } \\
\text { from R\&D to the marketplace, from order to delivery. }\end{array}$ & [65] \\
\hline Organizing for innovation does not present itself as a straightforward exercise & [51] \\
\hline The available technologies, the accessibility of knowledge and globalization & [70] \\
\hline $\begin{array}{l}\text { To compete globally and survive company needs to ensure that system and innovation process allows for continuous } \\
\text { improvement. }\end{array}$ & [8] \\
\hline $\begin{array}{l}\text { Customer demand a high variety of fair-priced but high quality and increasingly customized or even unique products } \\
\text { delivered quickly, and on time }\end{array}$ & [16] \\
\hline $\begin{array}{l}\text { The organization must be dynamic and ready to change and reorient core competencies to deal with a complex and dynamic } \\
\text { environment }\end{array}$ & [7] \\
\hline $\begin{array}{l}\text { The increasing demand of customers and the rapid development of information and communication technologies, business } \\
\text { confront intense competition in globalization, customization, service transformation }\end{array}$ & [34] \\
\hline $\begin{array}{l}\text { Competition pressure and unprecedented pace of change, the firm can no longer choose whether to concentrate on the } \\
\text { needs' customers or the anticipation of those of tomorrow. They must be excellent in both }\end{array}$ & [53] \\
\hline $\begin{array}{l}\text { Increase global competitiveness and demands to reduce cost, increase quality, improve customer service and ensure } \\
\text { continuity of supply }\end{array}$ & [43] \\
\hline Substantially changing the competitive landscape in the market which centers on competitive dynamics and digital system & [35] \\
\hline $\begin{array}{l}\text { Adapting to rapidly changing market conditions and technology shifts and generating continuous innovation, both of } \\
\text { offering and operations, have increasingly become requirements of business survival }\end{array}$ & [58] \\
\hline $\begin{array}{l}\text { Many firms face a dynamic environment with quickly changing market demands. In such an environment, firms may have } \\
\text { to continuously renew and improve their product platforms to achieve the desired flexibility }\end{array}$ & [20] \\
\hline $\begin{array}{l}\text { In the global competition, an immense pressure to innovate propels companies. The trend to produce more new knowledge- } \\
\text { intensive products or services and the rapid progress of information technologies arouse massive interest in knowledge } \\
\text { management for innovation }\end{array}$ & [69] \\
\hline $\begin{array}{l}\text { Organisations in all industries have to continuously reconfigure their structure and processes, sustain stability through } \\
\text { replication and optimization, ensure steady performances, and, at the same time, generate innovations to meet or create } \\
\text { future demands }\end{array}$ & {$[60]$} \\
\hline $\begin{array}{l}\text { Unexpected changes, turbulent environments, and global competition have become recurrent features in the current business } \\
\text { environment. }\end{array}$ & [6] \\
\hline $\begin{array}{l}\text { The company is facing increasingly fierce competition in the global economy. Previously sustainable competitive advantage } \\
\text { strategic are insufficient in the changed marked condition }\end{array}$ & [33] \\
\hline Innovation is dynamics process that requires a continuous, evolving, and mastered the management & [13] \\
\hline Within fierce market competition, only by depending on CI can an enterprise exist and develop & [1] \\
\hline
\end{tabular}

\section{Identification of the Fundamental Elements of CI Capabilities}

Based on a literature study, we identified 136 CI capability elements (see Table II). It is observed that a significant part of them (86\%) is intangible and only $14 \%$ is tangible. Organizational-based and knowledge-based elements dominate the intangible elements. On the other hand, when observed from internal and external resources, $81 \%$ of the elements still depends on the organization's internal resources. The use of external resources as CI is determining a factor for success is relatively small.

The proportion is illustrated in Fig. 2. These data show different results that most of the factors used are concerned more with real and monetary based CI elements [25]. The results of this study indicate that $86 \%$ of the CI capability 
determinants used in previous studies are included in the category of intangible factors. This results in the proper step that the value of a company today is mostly determined by intangible intellectual capital (IC) [36], [37]. However, the findings of this study show that the effort is still mainly (81\%) relying on internal resources of the company.

TABLE II

FUNDAMENTAL ELEMENTS OF CONTINUOUS INNOVATION CAPABILITIES (CIC)

\begin{tabular}{|c|c|}
\hline Contributor & A fundamental element of CIC \\
\hline [49] & Offensive management, hyperlearning process, \\
\hline [62] & Knowledge generation and transfer \\
\hline [17] & $\begin{array}{l}\text { Knowledge generation capability, learning alignment capability, Capability to integrate knowledge, the capability to } \\
\text { transfer and diffuse knowledge, and knowledge consolidation capability }\end{array}$ \\
\hline [63] & Knowledge generation, learning alignment, knowledge transferring and diffusion, knowledge retaining \\
\hline [19] & Creativity, organization learning, system design \\
\hline [16] & Operational effectiveness and strategic flexibility - exploitation and exploration \\
\hline [64] & Knowledge management \\
\hline [50] & Quality Assurance, Quality Management System \\
\hline [65] & Learning, knowledge \\
\hline [70] & External Contingency \\
\hline [44] & Employee participation (self-determination, a line of command, task/order) \\
\hline [51] & Ambidextrous organizations, the synergetic potential of technologies \\
\hline [45] & Individual competencies, skill, people abilities \\
\hline [66] & Learning, knowledge management \\
\hline [52] & System and organization \\
\hline$[8]$ & $\begin{array}{l}\text { Strategic (Leadership, strategic planning, human resources, process quality, customer satisfaction) and Operational } \\
\text { (Customer service, cost management, asset management, quality, productivity) }\end{array}$ \\
\hline [12] & $\begin{array}{l}\text { Stakeholders contribution, social capital, infrastructure for corporation, continuous improvement capability, and } \\
\text { strategic orientation }\end{array}$ \\
\hline [53] & Excellent in exploitation and exploration and excellent in incremental and radical innovation \\
\hline [39] & IT competences, project management, collaboration and communication, knowledge management \\
\hline$[40]$ & Concurrent engineering, creative engineering \\
\hline [54] & Combination of exploitation and exploration \\
\hline [43] & The ability to work together with partners \\
\hline [38] & The strategic role of ICT and customer and supplier relation \\
\hline$[67]$ & Knowledge management \\
\hline [55] & Good operational, efficiency \\
\hline [56] & $\begin{array}{l}\text { Applying enabling technology creativity, seizing market opportunities, aligning routes to markets, utilizing absorptive } \\
\text { capacity, enhancing organizational innovation, staging cultural }\end{array}$ \\
\hline [46] & Ideation capabilities, rules, system \\
\hline [57] & Leadership, adopter behavior, communicative adaptor \\
\hline [35] & $\begin{array}{l}\text { IT-enabled potential absorptive capability, IT-enabled Realized absorptive capability, IT-enabled social integration } \\
\text { capacity }\end{array}$ \\
\hline [34] & Entrepreneurship, resources management \\
\hline [68] & Knowledge management, knowledge assets, meta-model, macro process \\
\hline$[58]$ & Managerial coordination, communications mode, outside in perepective \\
\hline [10] & Scale effect of the cluster, innovative capacity, diffusion effect, and network effect \\
\hline [69] & Knowledge management \\
\hline [20] & Decision-making process, knowledge management \\
\hline [47] & Knowledge management, individual creativity \\
\hline [41] & ICT, Collaboration, learning \\
\hline [71] & Lean Thinking, Actors network \\
\hline [15] & Culture, individuals, leaders, organization, learning, P\&I system, and external interaction \\
\hline [59] & Agile organization \\
\hline$[60]$ & Operational excellence, innovation excellence, and strategic excellence \\
\hline [33] & Knowledge workers. \\
\hline$[61]$ & Inter-organizational networks, ecosystem networks \\
\hline [42] & Customer focus IT \\
\hline [13] & $\begin{array}{l}\text { Knowledge \& technology management, commercialization, project development, idea management, communication \& } \\
\text { networking, supportive culture \& structure, strategic management, and resources allocation }\end{array}$ \\
\hline$[1]$ & Knowledge innovation capability, production innovation capability, and market innovation capability \\
\hline [48] & Employee perception of previous innovation (intensity, failure) \\
\hline$[72]$ & The social network, intra-organisational networks \\
\hline [11] & The person-driven measure, internal process-driven measure, ideation-driven measure \\
\hline
\end{tabular}




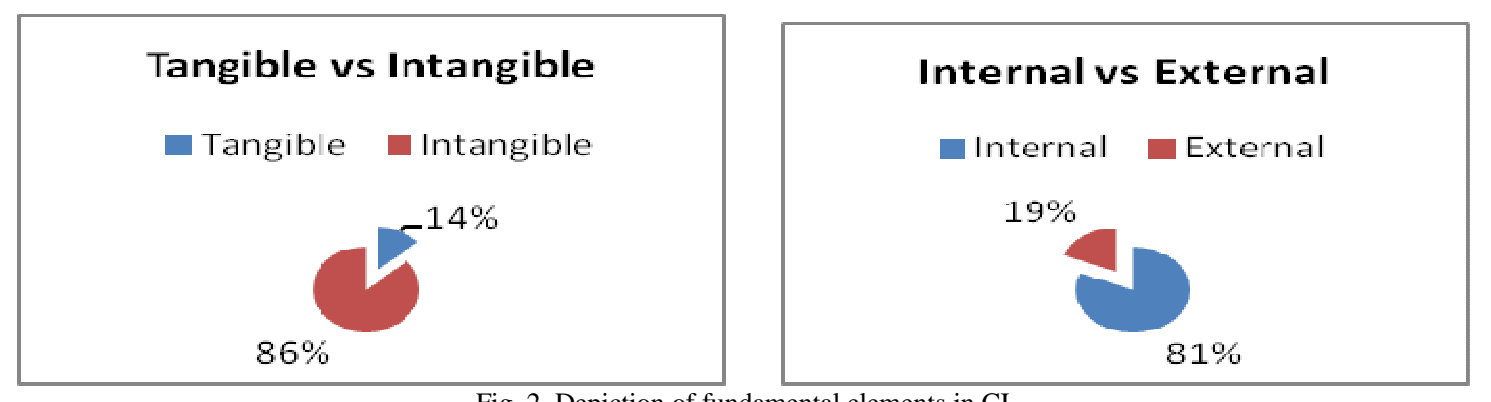

Fig. 2 Depiction of fundamental elements in CI

TABLE III

CONTINUOUS INNOVATION DEVELOPMENT STRATEGIES MAPPING

\begin{tabular}{|c|c|c|c|c|c|c|}
\hline Sources & $\begin{array}{l}\text { Technology } \\
\text {-Based }\end{array}$ & $\begin{array}{l}\text { People } \\
\text { based }\end{array}$ & $\begin{array}{l}\text { Organizational } \\
\text { \& System based }\end{array}$ & $\begin{array}{c}\text { Strategic } \\
\text { based }\end{array}$ & $\begin{array}{c}\text { Knowledge } \\
\text { Management based }\end{array}$ & $\begin{array}{c}\text { Collaborative \& } \\
\text { Connectivity-based }\end{array}$ \\
\hline [49] & & & $*$ & & $*$ & \\
\hline [62] & & & & & $*$ & \\
\hline [17] & & $*$ & $*$ & & $*$ & \\
\hline [63] & & & & & $*$ & \\
\hline [19] & & $*$ & $*$ & & $*$ & \\
\hline [16] & & & $*$ & $*$ & & \\
\hline$[64]$ & & & & & $*$ & \\
\hline$[50]$ & & & $*$ & & & \\
\hline [65] & & & & & $*$ & \\
\hline [70] & & & & & & $*$ \\
\hline [44] & & $*$ & & & & \\
\hline [51] & $*$ & & $*$ & & & \\
\hline [45] & & $*$ & & & & \\
\hline [66] & & & & & $*$ & \\
\hline [52] & & & $*$ & & & \\
\hline$[8]$ & & $*$ & $*$ & $*$ & & \\
\hline [12] & & & $*$ & $*$ & & $*$ \\
\hline$[53]$ & & & $*$ & $*$ & $*$ & \\
\hline [39] & $*$ & & $*$ & & $*$ & $*$ \\
\hline [40] & $*$ & & $*$ & & & \\
\hline [54] & & & $*$ & & & \\
\hline [43] & & & & & & $*$ \\
\hline [38] & $*$ & & & & & $*$ \\
\hline [67] & & & & & $*$ & \\
\hline [55] & & & $*$ & & & \\
\hline [56] & $*$ & $*$ & $*$ & $*$ & & \\
\hline [46] & & $*$ & $*$ & & & \\
\hline [57] & & $*$ & $*$ & & & \\
\hline [35] & $*$ & & & & & \\
\hline [34] & & $*$ & $*$ & & & \\
\hline [68] & & & & & $*$ & \\
\hline [58] & & & $*$ & $*$ & & \\
\hline [10] & & & $*$ & $*$ & & \\
\hline [69] & & & & & $*$ & \\
\hline [20] & & & $*$ & & $*$ & \\
\hline [47] & & $*$ & & & $*$ & \\
\hline [41] & $*$ & & & & $*$ & $*$ \\
\hline [71] & & & $*$ & & & \\
\hline [15] & & $*$ & $*$ & & & $*$ \\
\hline [59] & & & $*$ & & & \\
\hline [60] & & & $*$ & $*$ & & \\
\hline [33] & & $*$ & $*$ & & $*$ & \\
\hline [61] & & & & & & $*$ \\
\hline$[42]$ & $*$ & & & $*$ & & \\
\hline [13] & $*$ & & $*$ & $*$ & $*$ & \\
\hline$[1]$ & $*$ & & $*$ & $*$ & $*$ & \\
\hline$[48]$ & & $*$ & & & & \\
\hline [72] & & & $*$ & & & \\
\hline [11] & & $*$ & $*$ & & $*$ & \\
\hline
\end{tabular}




\section{The Mapping of CI Development Strategy}

Grouping 136 elements of CI capability did the first step of mapping CI development strategy as seen in Table 3. The grouping bases were adapted from six management principles [4] and seven organizational elements [15]. After that, we tried to propose six new CI development strategy formulations that can be the basis for further research (see Table 4). The mapping process was done by placing each CI capability element by the development strategy that has been formulated in Table 4.

Based on the mapping process, we could get a description of the proportion of CI development strategy as follows: technology-based $(11 \%)$, people based $(15 \%)$, organizational $\&$ system based $(32 \%)$, strategic-based $(11 \%)$, knowledgebased $(22 \%)$ and collaborative \& connectivity based $(9 \%)$.

It can be observed that current CI development strategies still focus on organizational and system based approach. Collaborative and connectivity development by utilizing external resources is still limited. With the rise of the knowledge-based economic system, there is a development of innovation strategy: Open Innovation (OI). With OI, innovation performance of a company no longer depends on its internal knowledge and technology. They need to adhere to external resources by building linkages with external parties. The tendency forces companies to change their innovation strategy and management from "do-it-yourself" mentality (closed innovation) to more open and collaborative system [73]. The OI paradigm illustrates how a company innovates by interacting with other organizations [74. In advanced and progressive organizations, transformation and change regarding continuous innovation, such as outside in perspective have occurred [58]. This new perspective requires a company to build collaboration and relationship with various external parties. Continuous innovation is a result of the sustainable interaction of operations, incremental improvement, and learning [17]. It must be considered that learning process does not occur only inside a company. The process will be more ideal when companies have good relationship and cooperation with institutions such as universities and research centers. In general, big companies with complex processes have the needs to obtain information and knowledge from external sources to maintain their efficiency and innovation performance. When consumers' demand changes faster, the level of competition rises. This challenge coupled with the fast development of technology requires companies to adapt because innovation activity in a company heavily depends on the presence of information and knowledge from internal and external resources [75]. Based on this literature study, the development strategies of CI with dependence on external resources are mostly limited to the collaboration of suppliers and consumers [15], [17], [12]. Future development strategies have the opportunities to further explore several linkages forms with external parties, such as horizontal linkages with competitors [24], [76], forward linkages with customers and distributors [76], [77], backward linkages with suppliers and consultants [78], [79], public linkages with universities, research centers, and governments [80], and informal linkages with association and exhibition committees [81].

TABLE IV

STRATEGIES TO CI DEVELOPMENT CCLASSIFICATION

\begin{tabular}{|c|c|c|}
\hline $\begin{array}{l}\text { Strategies for } \\
\text { CI } \\
\text { development }\end{array}$ & CI elements & Sources \\
\hline Technology & $\begin{array}{l}\text { The use of technology \& } \\
\text { production tools, information } \\
\text { and communication } \\
\text { technology, digital technology, } \\
\text { information system, } \\
\text { technology infrastructures }\end{array}$ & $\begin{array}{l}{[13]-[34]-} \\
{[35]-} \\
{[38]-[39]-} \\
{[40]-} \\
{[41]-[42]}\end{array}$ \\
\hline People & $\begin{array}{l}\text { Motivation, learning } \\
\text { capability, creative capability, } \\
\text { team cooperation capability, } \\
\text { and communication capability }\end{array}$ & $\begin{array}{l}{[1]-[15]-} \\
{[33]-[34]-} \\
{[43]-[19]-} \\
{[44]-[45]-} \\
{[46]-} \\
{[48]}\end{array}$ \\
\hline $\begin{array}{l}\text { Organization } \\
\text { \& System }\end{array}$ & $\begin{array}{l}\text { Managerial capability, culture, } \\
\text { resources allocation, } \\
\text { leadership, culture, decision } \\
\text { making, organizational } \\
\text { structure, project development } \\
\text { capability, customer service, } \\
\text { cost management, asset } \\
\text { management, quality, and } \\
\text { productivity }\end{array}$ & $\begin{array}{l}\text { [15]-[13]- } \\
{[16]-[8]-} \\
{[34]-[39]-} \\
{[19]-[46]-} \\
{[11]-[49]-} \\
{[50]-[51]-} \\
{[52]-[12]-} \\
{[53]-[54]-} \\
{[55]-[56]-} \\
{[57]-[58]-} \\
{[59]-[60]-} \\
{[61]}\end{array}$ \\
\hline Strategy & $\begin{array}{l}\text { Vision,/mission, strategic } \\
\text { management capability, } \\
\text { strategic excellence, and } \\
\text { strategic orientation, strategic } \\
\text { planning, commercialization, } \\
\text { market opportunities, aligning } \\
\text { routes to markets }\end{array}$ & $\begin{array}{l}{[13]-[16]-} \\
{[8]-} \\
{[12]-[60]}\end{array}$ \\
\hline $\begin{array}{c}\text { Knowledge } \\
\text { Management }\end{array}$ & $\begin{array}{lr}\text { Knowledge } & \text { generation } \\
\text { capability, } & \text { Knowledge } \\
\text { learning capability, knowledge } \\
\text { creation capability, knowledge } \\
\text { transferring } & \text { capability, } \\
\text { knowledge management, and } \\
\text { knowledge } & \text { consolidation } \\
\text { capability, learning process }\end{array}$ & $\begin{array}{l}{[1]-[17]-} \\
{[13]-} \\
{[20]-[47]-} \\
{[49]-} \\
{[62]-[63]-} \\
{[64]-} \\
{[65]-[66]-} \\
{[67]-} \\
{[68]-[69]}\end{array}$ \\
\hline $\begin{array}{c}\text { Collaborative } \\
\& \\
\text { Connectivity }\end{array}$ & $\begin{array}{l}\text { Open innovation, } \\
\text { interaction, } \\
\text { relationship, customer relation, } \\
\text { and supplier } \\
\text { connectivity, social network, } \\
\text { the ability to work together } \\
\text { with partners, } \\
\text { contingency }\end{array}$ & $\begin{array}{l}{[13]-[38]-} \\
{[43]-[70]-} \\
{[71]-[72]-} \\
{[10]}\end{array}$ \\
\hline
\end{tabular}

\section{CONCLUSIONS}

The result of this study proposes a new and more comprehensive definition of $\mathrm{CI}$, that is, as an innovation process and activity performed continuously, regularly, repeatedly, in an extended period, which results in beneficial impact for a company. Also, it will create a learning culture, of which an organization has the purpose to continuously improve and self-renew to adapt to the ever-changing 
consumers' need in the time being and the future. This definition is more directive in that $\mathrm{CI}$ is a continuous process in building and shaping innovation capabilities to increase a company's potential to produce innovation performance (combination of incremental or radical innovation) continuously.

Moreover, based on the mapping process, we got a description of the proportion of CI development strategy as follows: technology-based (11\%), People based (15\%), organizational \& system based (32\%), strategic-based (11\%), knowledge-based (22\%), and collaborative and connectivity based $(9 \%)$. It can be observed that current CI development strategies still focus on organizational, system based approach, and primarily (81\%) rely on the internal resource of the company. Collaborative and connectivity development by utilizing external resources is still limited. In this digital and internet era, which provides connectivity and the switch of the concept of own economic to sharing economy, companies will have significant potentials to work on innovation collaboratively. In future perspectives, CI concept development should consider open innovation instead of today's "do-it-yourself" mentality (closed innovation).

\section{ACKNOWLEDGMENT}

We would like to thank University of Surabaya (UBAYA) for permits and support this research funding.

\section{REFERENCES}

[1] S. H. Chen, "The influencing factors of sustainable enterprise innovation: an empirical study," Sustainability, vol. 8, no. 5, pp. 425. April 2016

[2] F. Rothaermel and A. Hess, "Innovation strategies combined," MIT Sloan Management Review, Vol. 51, no.3, pp.13, Spring 2010

[3] R. Garud, J. Gehman, and A.Kumaraswamy, "Complexity arrangements for sustained innovation: lesson form \#M corporation," Organization Studies, Vol.32, no.6, pp.737-767, 2011

[4] A. Steiber, The Google model: managing continuous innovation in a rapidly changing world, Springer, 2014

[5] N.S. Madonsela, S.C.Mukwakungu, C.Mbohwa, “ Continuous innovation as a fundamental enabler for sustainable business practices, " Procedia Manufacturing, vol.8, pp.278-283, 2017

[6] A. M. Nisula and A. Kianto, "Evaluating and developing innovation capabilities with a structured method," Interdisciplinary Journal of Information, Knowledge, and Management, vol. 8, pp. 59-82, 2013

[7] G. Davison, and P. Hyland, "Continuous innovation in a complex and dynamic environment: The case of the Australian health service," International Journal of Technology Management \& Sustainable Development, vol. 5, no. 1, pp. 41-59, April 2006

[8] C.A. Soosay, and R.L. Chapman, "An empirical examination of performance measurement for managing continuous innovation in logistics," Knowledge and process management, vol. 13, no. 3, pp. 192-205, July 2006

[9] C.H.Seelos, and J. Mair, "What Determines the Capacity for Continuous Innovation in Social Sector Organizations?", Center on philanthropy and civil society, Tech.Rep. Jan 2012

[10] X.M Xie, S.X. Zeng, and C.M. Tam, "Towards continuous innovation for regional high-tech industrial clusters," Innovation, vol. 13, no. 3, pp. 361-375, Sept 2011

[11] M. Saunila, and M. Saunila, "Managing continuous innovation through performance measurement," Competitiveness Review: An International Business Journal, vol. 27, no. 2, pp. 179-190, 2017

[12] L.C.R. Carpinetti, M.C. Gerolamo, and E.V.C. Galdámez, "Continuous innovation and performance management of SME clusters," Creativity and Innovation Management, vol.16, no.4, pp. 376-385, Nov 2007
[13] M.N.A. Rahman, M. Doroodian, Y. Kamarulzaman, and N Muhamad, "Designing \& validating a model for measuring the sustainability of overall innovation capability of small \& mediumsized enterprises," Sustainability, vol. 7, no. 1, pp. 537-562, Jan 2015

[14] T. Kalling, " The lure of simplicity: learning perspectives on innovation," European Journal of Innovation Management, vol.10, no. 1, pp.65-89, 2007

[15] A. Steiber and S. Alänge, "A corporate system for continuous innovation: the case of Google Inc," European Journal of Innovation Management, vol. 16, no. 2, pp. 243-264, 2013

[16] H. Boer, and F. Gertsen, "From continuous improvement to continuous innovation: a (retro)(per) spective," International Journal of Technology Management, vol. 26, no. 8, pp. 805-827, 2003

[17] H.Boer., et al., "Knowledge and continuous innovation: the CIMA methodology," International Journal of Operations \& Production Management, vol. 21, no. 4, pp. 490-504, 2001

[18] M.Tushman and C. O'Reilly, Winning through Innovation: A Practical Guide to Leading Organizational Change and Renewal, Harvard Business School Press, Boston, MA, 1997

[19] R.E. Cole, "From continuous improvement to continuous innovation." Quality Management Journal, vol. 8, no. 4, pp. 7-21, 2001

[20] M. Pasche, and M. Magnusson, "Continuous innovation and improvement of product platforms," International Journal of Technology Management, vol. 56, no. 2/3/4, pp. 256-271, 2011

[21] P. Hyland, and HA. Boer, "Continuous innovation framework: some thoughts for consideration," in the proceedings 7th CINet Conference, Lucca, Italy, Sept 2006

[22] E. De Oliveira Teixeira and W.B. Werther, "Resilience: Continuous renewal of competitive advantages," Business Horizons, vol.56, no. 3, pp. 333-342, May-Jun 2013

[23] C.L. Wang and P.K. Ahmed, "Dynamic capabilities: A review and research agenda," International Journal of management reviews, vol. 9, no. 1, pp. 31-51, Feb 2007

[24] R. Burgelman, M.A. Maidique, S.C. Wheelwright, "Strategic Management of Technology and Innovation." McGraw-Hill, New York, pp.10-14. 2001

[25] M. Elmquist, and P.LeMasson, "The value of a failed'R\&D project: an emerging evaluation framework for building innovative capabilities," R\&D Management, vol. 39, pp. 136-152, Feb 2009

[26] M.H. Chen and Y.J Yang, "Typology and performance of new ventures in Taiwan. A model based on opportunity recognition and entrepreneurial creativity", International Journal of Entrepreneurial Behaviour \& Research, vol. 15, pp. 398-414. 2009

[27] O. Bertrand,"Effect of foreign acquisitions R\&D activity: evidence from firm-level data for France," Research Policy, Vol.38, pp.10211031,2009

[28] C, E.Hull and J.G.Covin,'Learning capability, technological parity, and innovation mode use," Journal of Product Innovation Management, vol. 27, no.1, pp. 97-114, 2010

[29] C.H. Wang, I.Y. Lu, and C.B. Chen, "Evaluating firm technological innovation capability under uncertainty," Technovation, vol. 28, no. 6, pp. 349-363, June 2008

[30] J. Elkington, "The Triple Bottom Line For 21 st Century Business" Business \& Sustainable Development, edited by Richard Starkey, Richard Welford, London: Earthscan, pp. 20-52, 2004

[31] G. Xiang, "Some thinking about the enterprise's sustainable innovation," In Proceedings of the China-USA Seminar on the Technological Innovation Management the International Conference, Beijing, China, pp. 24-27, 2000

[32] D. Teece, and G. Pisano, "The dynamic capabilities of firms: an introduction," Industrial \& corporate change, Vol. 3, pp. 537-556, Sept 1994

[33] T. Toivonen, "Continuous innovation-combining Toyota Kata\&TRIZ for sustained innovation," Procedia Engineering, vol. 131, pp. 963974,2015

[34] S.S.C. Shang, S.H Wu, and C.Y. Yao, "A dynamic innovation model for managing capabilities of continuous innovation," International Journal of Technology Management, vol. 51, no. 2-4, pp. 300-318, 2010

[35] K.D. Joshi, L. Chi, A. Datta, and S. Han, "Changing the competitive landscape: Continuous innovation through IT-enabled knowledge capabilities," Information Systems Research, vol. 21, no. 3, pp. 472495, Sept 2010 
[36] L. Užienè," Open innovation, knowledge flows and intellectual capital," Procedia-Social and Behavioral Sciences, vol. 213, pp.10571062. 2015

[37] B Marr, D Gray, A Neely, "Why do firms measure their intellectual capital?," Journal of Intellectual Capital, vol.4 no. 4, pp. 4, 2003

[38] A. Ciappini, M. Corso, and A. Perego, "From ICT outsourcing to strategic sourcing: managing customer? supplier relations for continuous innovation capabilities," International Journal of Technology Management, vol. 42, no.1-2, pp. 185-203, 2008

[39] S.R. Gordon, and M. Tarafdar, "How do a company's information technology competencies influence its ability to innovate?," Journal of Enterprise Information Management, vol.20, no. 3, pp. 271-290, 2007

[40] J.J.Y. Lin, "Creativity engineering for continuous and discontinuous innovation," International Journal of Innovation and Technology Management, vol. 4, no. 02, pp. 209-224, June 2007

[41] R. Balocco, A. Ciappini, and M. Corso, "The impact of ICT sourcing on ICT organization, competences, and continuous innovation," International Journal of Technology Management, vol. 60, no. 3/4, pp. 179-201, 2012

[42] V.K. Narayanan, "Customer-focused IT: a process of continuous value innovation," Strategy \& Leadership, vol. 43, no. 4, pp. 11-17, 2015

[43] C.A. Soosay, P.W. Hyland, and M. Ferrer, "Supply chain collaboration: capabilities for continuous innovation," Supply Chain Management: An International Journal, vol.13, no.2, pp. 160-169, 2008

[44] T. Tonnessen, "Continuous innovation through company-wide employee participation," The TQM Magazine, vol. 17, no. 2, pp. 195207, 2005

[45] C.A. Soosay, "An empirical study of individual competencies in distribution centers to enable continuous innovation," Creativity and Innovation Management, vol. 14, no. 3, pp. 299-310, Aug 2005

[46] J. Björk, P. Boccardelli, and M. Magnusson, "Ideation capabilities for continuous innovation," Creativity and innovation management, Vol.19, no.4, pp.385-396, Nov 2010

[47] A. Kianto, "The influence of knowledge management on continuous innovation," International Journal of Technology Management, vol. 55, no. $1 / 2$, pp. $110-121,2011$

[48] G.H. Chung, J.N. Choi, and J. Du, "Tired of innovations? Learned helplessness and fatigue in the context of continuous streams of innovation implementation," Journal of Organizational Behavior. April 2017

[49] Y. Baba, "The dynamics of continuous innovation in scale-intensive industries," Strategic Management Journal, vol. 10, no.1, pp. 89-100, Jan 1989

[50] M. Pivka, and M. Mulej, "Requisitely holistic ISO 9000 audit leads to continuous innovation/improvement," Cybernetics and Systems: An International Journal, vol. 35, no. 4, pp. 363-378, Jan 2004

[51] B. Van Looy, T. Martens, and K. Debackere, "Organizing for continuous innovation: On the sustainability of ambidextrous organizations," Creativity and Innovation Management, vol. 14, no. 3, pp. 208-221, Aug 2005

[52] S.M. Ko, and K.L. Yung, "Function deployment model for continuous and discontinuous innovation product development," International Journal of Innovation and Technology Management, vol. 3, no. 01, pp. 107-128, March 2006

[53] M. Corso, A. Martini, and L. Pellegrini, "Innovation at the intersection between exploration, exploitation, and discontinuity," International Journal of Learning and Intellectual Capital, vol. 6, no.4, pp. 324-340, Oct-Dec 2009

[54] B.T. Laugen, and H. Boer, "Continuous innovative practices and operational performance," International Journal of Technology Management, vol. 44, no. 3-4, pp. 338-353, 2008

[55] M. Magnusson, and A. Martini, "Dual organizational capabilities: from theory to practice-the next challenge for continuous innovation,' International Journal of Technology Management, vol. 42, no.1-2, pp. $1-19,2008$

[56] C.L. Chen, and Y.L. Jaw, "Building global dynamic capabilities through innovation: A case study of Taiwan's cultural organizations," Journal of engineering and technology management, vol. 26, no. 4, pp. 247-263, Dec 2009

[57] M.F. Hazeldine, and M.P. Miles, "An exploratory role analysis of opinion leaders, adopters, and communicative adopters with dynamically continuous innovation," Journal of Applied Business Research, vol. 26, no. 4, pp. 117, July-Aug 2010
[58] S. Denning, "Reinventing management: the practices that enable continuous innovation," Strategy \& Leadership, vol. 39, no. 3, pp. 1624, 2011

[59] S. Denning, "Why Agile can be a game changer for managing continuous innovation in many industries," Strategy \& Leadership, vol. 41, no. 2, pp. 5-11, 2013

[60] A. Martini, B.T. Laugen, L. Gastaldi, and M. Corso, "Continuous innovation: towards a paradoxical, ambidextrous combination of exploration and exploitation," International Journal of Technology Management, vol. 61, no. 1, pp. 1-22, 2013

[61] L. Gastaldi, F.P. Appio, A. Martini, and M. Corso, "Academics as orchestrators of continuous innovation ecosystems: towards the fourth generation of CI initiatives," International Journal of Technology Management, vol. 68, no. 1-2, pp. 1-20, 2015

[62] M. Corso, and S. Pavesi, "How management can foster continuous product innovation," Integrated Manufacturing Systems, vol. 11.no.3, pp. 199-211, 2000

[63] R.L. Chapman, C.E. O’Mara, S. Ronchi, and M. Corso, “Continuous product innovation: A comparison of key elements across different contingency sets," Measuring business excellence, vol. 5, no.3, pp. 1623, 2001

[64] G. Verona, and D. Ravasi, "Unbundling dynamic capabilities: an exploratory study of continuous product innovation," Industrial and corporate change, vol. 12, no.3, pp. 577-606, Jun 2003

[65] R. Smeds, and H. Boer, "Continuous innovation and learning in industrial organizations," Knowledge and process management, vol. 11, no.4, pp. 225-227, Oct 2004

[66] R.L. Chapman, and M.G. Magnusson, "Continuous innovation, performance and knowledge management: an introduction,' Knowledge and Process Management, vol. 13, no. 3, pp. 129-131, July 2006

[67] M. Corso, A. Martini, and R. Balocco, "Organising for continuous innovation: the community of practice approach," International Journal of Technology Management, vol. 44, no. 3-4, pp. 441-460, 2008

[68] J. Xu, R. Houssin, E. Caillaud, and M. Gardoni, "Macro process of knowledge management for continuous innovation," Journal of Knowledge Management, vol. 14, no. 4, pp. 573-591, 2010

[69] J. Xu, R. Houssin, E. Caillaud, and M. Gardoni, "Fostering continuous innovation in design with an integrated knowledge management approach," Computers in Industry, vol. 62, no. 4, pp. 423-436, May 2011

[70] C.A. Soosay, and P.W. Hyland, "Effect of firm contingencies on continuous innovation," International Journal of Innovation and Technology Management, vol. 2, no.02, pp. 153-169, Jun 2005

[71] T. Papadopoulos, "Continuous innovation through lean thinking in healthcare: the role of dynamic actor associations," International Journal of Technology Management, vol. 60, no. 3/4, pp. 266-280, 2012

[72] A. Karlsson, and J. Björk, "Establishing and managing a network for continuous innovation: Invoking organizational pressure," Creativity and Innovation Management, vol. 26, no. 2, pp. 128-141, 2017

[73] O. Gassmann, "Opening up the innovation process: towards an agenda," R\&d Management, vol. 36, no. 3, pp. 223-228, May 2006

[74] H. Chesbrough, "Open innovation: Where we have been and where we are going," Research-Technology Management, vol. 55, no.4, pp. 2027, 2012

[75] M. Du Plessis, "The role of knowledge management in innovation,' Journal of knowledge management, vol. 11, no. 4, pp. 20-29, 2007

[76] S. Roper, J. Du, and J.H. Love, "Modelling the innovation value chain," Research Policy, vol. 37, pp. 961-977, July 2008

[77] A.W. Joshi, and S. Sharma, "Customer knowledge development: antecedents and impact on new product performance," Journal of Marketing, vol. 68, pp. 47-59, Oct 2004

[78] P.M. Horn, "The changing nature of innovation," Research Technology Management, vol. 48, pp. 28-33, Dec 2005

[79] D.J. Smith, and D. Tranfield, "Talented suppliers? Strategic change and innovation in the UK aerospace industry," R\&D Management, vol. 35, pp. 37-49, Jan 2005

[80] S. Roper, N. Hewitt-Dundas, and J.H. Love, “An ex-ante evaluation framework for the regional benefits of publicly supported R\&D projects," Research Policy. Vol. 33, pp. 487-509, April 2004

[81] R. Harris and Q. Li, "Exporting, R\&D, and absorptive capacity in UK establishments," Oxford Economic Papers, vol. 61, pp. 74-103, March 2009 
애나 3t6h-414

Ye 1, ho 2 [2011]

\section{International Journal on} Advanced Science Eng i ne ering Information Technology

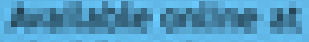

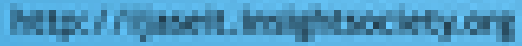

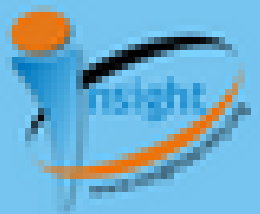

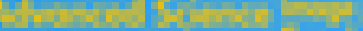

tat hathing

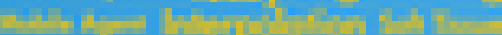

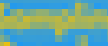

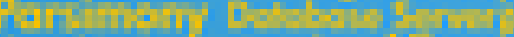

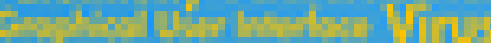

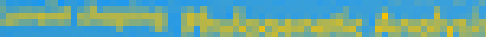

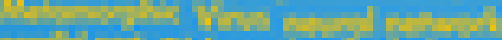

4t-14 


\section{Source details}

\section{International Journal on Advanced Science, Engineering and Information Technology}

\section{Scopus coverage years: from 2015 to Present}

Publisher: INSIGHT - Indonesian Society for Knowledge and Human Development

Subject area: Agricultural and Biological Sciences: General Agricultural and Biological Sciences

Engineering: General Engineering

Source type: Journal

i Improved CiteScore methodology

CiteScore 2020 counts the citations received in 2017-2020 to articles, reviews, conference papers, book chapters and data papers published in 2017-2020, and divides this by the number of publications published in 2017-2020. Learn more >

CiteScore

2020

$1.9=\frac{2,538 \text { Citations } 2017-2020}{1,345 \text { Documents } 2017-2020}$

Calculated on 05 May, 2021
CiteScoreTracker 2021 (1)

$1.6=\frac{1,887 \text { Citations to date }}{1,193 \text { Documents to date }}$

Last updated on 04 September, 2021 . Updated monthly

CiteScore rank 2020 (i)

Category Rank Percentile

Agricultural and

Biological Sciences

\#72/209

65th

- General Agricultural

and Biological

Sciences

\section{Engineering}

L General Engineering

\#127/297

57 th

View CiteScore methodology $>$ CiteScore FAQ $>$ Add CiteScore to your site $\mathbb{O}$ 

About Scopus
Русский язык
Privacy matters
ELSEVIER Terms and conditions $\pi \quad$ Privacy policy $\pi$
Copyright (C) Elsevier B.V ז. All rights reserved. Scopus ${ }^{\circledR}$ is a registered trademark of Elsevier B.V.
We use cookies to help provide and enhance our service and tailor content. By continuing, you agree to the use
of cookies. 


\section{Source details}

\section{International Journal on Advanced Science, Engineering and Information Technology}

\section{Scopus coverage years: from 2015 to Present}

Publisher: INSIGHT - Indonesian Society for Knowledge and Human Development

Subject area: Agricultural and Biological Sciences: General Agricultural and Biological Sciences

Engineering: General Engineering

Source type: Journal

i Improved CiteScore methodology

CiteScore 2020 counts the citations received in 2017-2020 to articles, reviews, conference papers, book chapters and data papers published in 2017-2020, and divides this by the number of publications published in 2017-2020. Learn more >

CiteScore

2020

$1.9=\frac{2,538 \text { Citations } 2017-2020}{1,345 \text { Documents } 2017-2020}$

Calculated on 05 May, 2021
CiteScoreTracker 2021 (1)

$1.6=\frac{1,887 \text { Citations to date }}{1,193 \text { Documents to date }}$

Last updated on 04 September, 2021 . Updated monthly

CiteScore rank 2020 (i)

Category Rank Percentile

Agricultural and

Biological Sciences

\#72/209

65th

- General Agricultural

and Biological

Sciences

\section{Engineering}

L General Engineering

\#127/297

57 th

View CiteScore methodology $>$ CiteScore FAQ $>$ Add CiteScore to your site $\mathbb{O}$ 

About Scopus
Русский язык
Privacy matters
ELSEVIER Terms and conditions $\pi \quad$ Privacy policy $\pi$
Copyright (C) Elsevier B.V ז. All rights reserved. Scopus ${ }^{\circledR}$ is a registered trademark of Elsevier B.V.
We use cookies to help provide and enhance our service and tailor content. By continuing, you agree to the use
of cookies. 


\section{International Journal on \\ Advanced Science \\ En g i n e e ri n g \\ Information Technology}

HOME ARCHIVES

International Journal on Advanced Science, Engineering and Information Technology

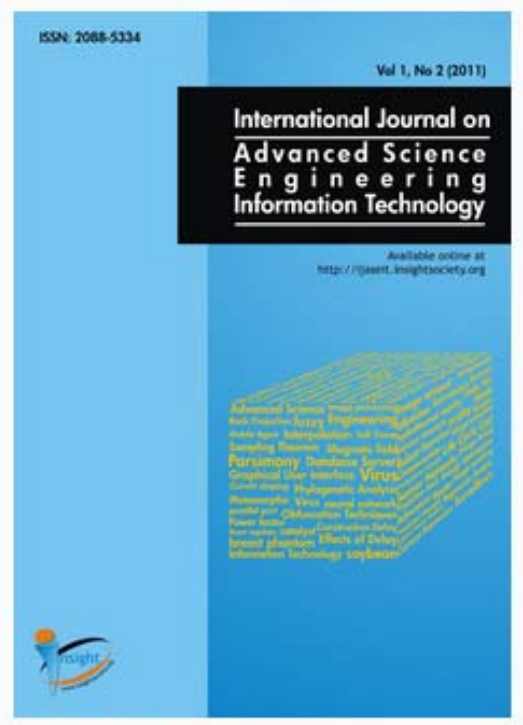

International Journal on Advanced Science, Engineering and Information Technology (IJASEIT) is an international peer-reviewed journal dedicated to interchange for the results of high quality research in all aspect of science, engineering and information technology. The journal publishes state-of-art papers in fundamental theory, experiments and simulation, as well as applications, with a systematic proposed method, sufficient review on previous works, expanded discussion and concise conclusion. As our commitment to the advancement of science and technology, the IJASEIT follows the open access policy that allows the published articles freely available online without any subscription.

\section{Frequency. 6 issues per year}

\section{DOI : 10.18517}

ISSN : 2088-5334

e-ISSN : 2460-6952

Important Dates:

Paper Submission Date: Any time

Online Publication Date: Last date of February, April, June, August, October, December

[NEW 2020 Acceptance Rate: $14.32 \%$ | 2019 Acceptance Rate: $17.85 \%$ | 2018 Acceptance Rate: $18.20 \%$

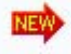

WASEIT has launched a new template since Vol. 11 (2021) No.1: Template IJASEIT 2021

[NEW SCImago $2020 \rightarrow 0.22 \mid \mathrm{Q} 3$ and Scopus Cite Score $2020 \rightarrow 1.9 \mid 65^{\text {th }}$ percentile / 2 nd quartile Scopus.

International Journal on Advanced Science, Engineering and Information Technology is indexed in Elsevier Scopus database 


\section{Editorial Team}

\section{Editor in Chief :}

Rahmat Hidayat, (Scopus ID: 57191265401) Politeknik Negeri Padang, INDONESIA

\section{Associate Editors :}

Taufik, (Scopus ID: 23670809800), California Polytechnic State University, USA Haitham Alali, (Scopus ID: 49963007000), Amman Arab University, JORDAN Wan Mohtar Wan Yusoff, (Scopus ID: 15019967700), Univ. Kebangsaan Malaysia, MALAYSIA Halimah Badioze Zaman, (Scopus ID: 25825801600), Univ. Kebangsaan Malaysia, MALAYSIA Son Radu, (Scopus ID: 7005251005), Universiti Putra Malaysia, Malaysia, MALAYSIA Mohd Razi Ismail, (Scopus ID: 25957691400), Universiti Putra Malaysia, MALAYSIA Takashi Oku, (Scopus ID: 56275094900), Prefectural University of Hiroshima, JAPAN Kohei Nakano, (Scopus ID: 7402011766), Gifu University, JAPAN Nurul Huda, (Scopus ID: 6701695514), Universiti Malaysia Sabah, MALAYSIA Yandra Arkeman, (Scopus ID: 55946558300), Bogor Agriculture University, INDONESIA Sate Sampattagul, (Scopus ID: 7801640861), Chiangmai University, THAILAND Peeyush Soni, (Scopus ID: 9248907800), Asian Institute of Technology, THAILAND Yolanda Lechon Perez, (Scopus ID: 6602826000), Ciemat, Madrid, SPAIN Gabriele Arcidiacono (Scopus ID: 56656284600), G. Marconi University, ITALY Alessandra Pieroni (Scopus ID: 25929524500). , Marconi International University, Florida - USA Nguyen Hay , (Scopus ID: 15834645900) Nong Lam University. VIETNAM Rita Muhamad Awang, (Scopus ID: 55957782400 ), Universiti Putra Malaysia, MALAYSIA Anton S Prabuwono, (Scopus ID: 18134309800), King Abdulaziz Univ, SAUDI ARABIA P Mangala C S De Silva, (Scopus ID: 7006461145), University of Ruhuna, SRI LANKA Bich Huy Nguyen, (Scopus ID: 36191086100 ), Nong Lam University, VIETNAM Paul Kristiansen, (Scopus ID: 23097563600), University of New England, AUSTRALIA Amitava Basu, (Scopus ID: 21833738300), Bidhan Chandra Krishi Vidyalaya, INDIA Shahrul Azman Mohd Noah, (Scopus ID: 35087633200), Universiti Kebangsaan Malaysia, MALAYSIA Luca Di Nunzio (Scopus ID:57195199010), University of Rome Tor Vergata, ITALY Rocco Fazzolari (Scopus ID:36469997900), University of Rome Tor Vergata, ITALY Ruben Paul Borg (Scopus ID:55246483600), L-Universit ta' Malta, Msida, Malta

\section{Editors :}

Nurhamidah, (Scopus ID: 57191636504), Andalas University, INDONESIA Ario Betha Juansilfero, (Scopus ID: 57189369470), Kobe University, JAPAN Zairi Ismael Rizman, (Scopus ID: 36959761800), Universiti Teknologi MARA (UiTM) (Terengganu) MALAYSIA Shahreen Kasim, (Scopus ID: 36155431900 ), Universiti Tun Hussein Onn - MALAYSIA Chi-Hua Chen, (Scopus ID: 35799698800), National Chiao Tung University, TAIWAN Abrar Ismardi, (Scopus ID: 26633102900), Telkom University - INDONESIA 


\section{Vol. 8 (2018) No. 3}

\section{Articles}

Methods to Characterize Fly Ash Quality in the Field

- Triwulan, Khorin Agus Priadana, Januarti Jaya Ekaputri

pages: 646-651 Full text DOl:10.18517/ijaseit.8.3.4312

Finite Element Analysis of Osteosynthesis Miniplate for the Reconstruction of Parasymphyseal Compound Fracture

Muslim Mahardika, Romario Aldrian Wicaksono, Maria Goreti Widiastuti, Budi Arifvianto, - Suyitno pages: 652-656 Full text DOI:10.18517/ijaseit.8.3.4465

Neutronic Analysis of a Thorium-Fueled Reduced Moderation Boiling Water Reactor

Dayu Fajrul Falaakh, Alexander Agung, Andang Widi Harto

pages:657-663 Full text DOI:10.18517/ijaseit.8.3.2834

Tobermorite Microstructure Resulted from Reaction of Low Content of Silica of Rice Husk Ash and Quicklime Mixture

Bakri Bakri

pages: 664-670 Full text DOl:10.18517/ijaseit.8.3.1892

Identification of Slope Stability Analysis

Ika Juliantina, Yulindasari Sutejo, Ratna Dewi, Bimo Brata Adhityia, Reffanda Kurniawan Rustam pages: 671-677 Full text DOl:10.18517/ijaseit.8.3.2685

Preliminary Investigations for Policy Framework to Regulate the Utilisation of Residual Strength of Demolition Waste Aggregate in Cement Concrete Mix

M. R. Raja Shekhara, Reshma. E. K.

pages: 678-684 Full text DOI:10.18517/ijaseit.8.3.4175

Capillary Shock Phenomenon of Groundwater at the Beginning of Rainy Season

Darwis Panguriseng, Abd. Rakhim Nanda

pages: 685-693 Full text DOl:10.18517/ijaseit.8.3.3818

Conversion of Polypropylene Plastic Waste Into Liquid Fuel with Catalytic Cracking Process Using Al2O3 as Catalyst

Devi Rachmadena, Muhammad Faizal, Muhammad Said

pages: 694-700 Full text DOI:10.18517/ijaseit.8.3.2586

Farm Machinery Development and Utilization System Policies for Small-Scale Rice Farming

Ujang Paman, Saipul Bahri, - Asrol, - Khairizal, Hajry Arief Wahyudy

pages: 701-707 Full text DOl:10.18517/ijaseit.8.3.1758 
Influence of Moisture Content to the Physical Properties of Unhusk Rice Grain

Renny Eka Putri, Santosa Santosa, Muhammad Makky

pages: 708-713 Full text DOI:10.18517/ijaseit.8.3.3455

Parasitizations Levels and Temperature Tolerance of Rice Bug (Leptocorisa oratorius Fabricius) Egg

Parasitoids: Mass Rearing for Biological Control

Fri Maulina, Novri Nelly, Hidrayani Hidrayani, Hasmiandy Hamid

pages:714-719 Full text DOl:10.18517/ijaseit.8.3.1241

Oil-Palm Plantation Identification from Satellite Images Using Google Earth Engine

Supattra Puttinaovarat, Paramate Horkaew

pages: $720-726$ Full text DOl:10.18517/ijaseit.8.3.2415

Soil Mounding Practices Towards Yield Performances of Oil Palm on Peat Soil

Shampazuraini binti Samsuri, Husein bin Abdul Gani, Siti Aminah Binti Wahab, Nurul Farhana Hazira $H$ pages: 727-731 Full text DOI:10.18517/ijaseit.8.3.2751

An Immunological-Based Simulation: A Case Study of Risk Concentration for Mobile Spam Context Assessment

Kamahazira Zainal, Mohd Zalisham Jali

pages: 732-742 Full text DOl:10.18517/ijaseit.8.3.2719

Implementation of Otsu's Method in Vein Locator Devices

Gwo-Jia Jong, Hendrick Hendrick, Zhi-Hao Wang, Dedi Kurniadi, Aripriharta Aripriharta, Gwo-Jiun Horng pages: $743-748$ Full text DOI:10.18517/ijaseit.8.3.4414

A Novel Packet Scheduling with Channel-Aware Algorithm for Multi-Service Flow in the LTE Network

Ida Nurcahyani, Sisdarmanto Adinandra

pages: 749-755 Full text DOl:10.18517/ijaseit.8.3.5579

Component-connected Feature for Signature Identification

Naeli Umniati, Achmad Benny Mutiara, Tubagus Maulana Kusuma, Suryarini Widodo pages:756-761 Full text DOl:10.18517/ijaseit.8.3.2880

Different Applications of the Genetic Mutation Operator for Symetric Travelling Salesman Problem

Velin Kralev

pages: 762-770 Full text DOl:10.18517/ijaseit.8.3.4867

\section{Continuous Innovation: A Literature Review and Future Perspective}

Benny Lianto, M. Dachyar, Tresna Priyana Soemardi

pages: 771-779 Full text DOI:10.18517/ijaseit.8.3.4359 
Synthesis and Optimization of Acrylic-N-Acryloxysuccinimide Copolymer Microspheres

Alizar Ulianas, Nurlely Nurlely, Lee Yook Heng, Tan Ling Ling pages: 780-784 Full text DOl:10.18517/ijaseit.8.3.3336

Tree Vegetation Structure at the Realolo Village Bantimurung Bulusaraung National Park Maros District Muhammad Wiharto, Siti Fatmah Hiola, Syamsinar S, Muhammad Wijaya, Hamka L pages: 785-791 Full text DOI:10.18517/ijaseit.8.3.4725

Compression Behavior of Fibrous Peat Stabilized with Admixtures of Lime CaCO3+Rice Husk Ash and Lime CaCO3+Fly Ash

Noor Endah Mochtar, Faisal Estu Yulianto

pages: 792-798 Full text DOl:10.18517/ijaseit.8.3.4317

Comparison of WF \& Tubular Links on the Eccentrically Brace Frame System due to Cyclic Loads

Budi Suswanto, Aniendhita Rizki Amalia, Endah Wahyuni, Najibullah Al Farisy

pages: 799-804 Full text DOl:10.18517/ijaseit.8.3.4337

Development of Thermal Insulation Material Using Coconut Fiber to Reuse Agricultural Industrial Waste Ryushi Kimura, Masato Ohsumi, Lusi Susanti

pages: 805-810 Full text DOI:10.18517/ijaseit.8.3.4610

Disinfection of Escherichia coli Bacteria Using Combination of Ozonation and Hydrodynamic Cavitation Method with Venturi Injector

Eva Fathul Karamah, Fitri Amalia, Fitri Amalia, Setijo Bismo, Rioneli Ghaudenson, Setijo Bismo, Rioneli Ghaudenson

pages:811-817 Full text DOl:10.18517/ijaseit.8.3.3922

Adsorption of Phosphate in Aqueous Solutions Using Manganese Dioxide

Yunus Fransiscus, Restu K. Widi, Gracia O. Aprilasti, Marta D. Yuharma pages: 818-824 Full text DOI:10.18517/ijaseit.8.3.3866

The Effect of TiO2 Particles Addition on The Characteristics of Polysulfone Membrane

Nurul Nadiah Said, Fazlena Hamzah, Nur Azrini Ramlee, Nur Najwa Yunus

pages: 825-831 Full text DOI:10.18517/ijaseit.8.3.3901

Physicochemical Properties of Duck Feet Collagen with Different Soaking Time and Its Application in Surimi

Chong Hui Theng, Nurul Huda, Nik Aisyah Nik Muhammad, Chatarina Wariyah, Haslaniza Hashim pages:832-841 Full text DOl:10.18517/ijaseit.8.3.2670 